\title{
Panjang Karapas dan Laju Pertumbuhan Spesifik Kepiting Bakau (Scylla serrata) yang diberi Jenis Pakan Berbeda di Area Ekowisata Kampung Kepiting, Bali
}

\author{
Ni Desak Putu Ida Suryani ${ }^{\text {a* }}$ Pande Gde Sasmita Julyantoro ${ }^{\text {, }}$ \\ Ayu Putu Wiweka Krisna Dewi ${ }^{c}$ \\ a Program Studi Manajemen Sumberdaya Perairan, Fakultas Kelautan dan Perikanan, Universitas Udayana Kab Badung, Provinsi Bali, \\ Indonesia \\ * Penulis koresponden. Tel.: +62-821999475026 \\ Alamat e-mail: desaksuryani26@gmail.com
}

Diterima (received) 6 Juli 2017; disetujui (accepted) 24 Agustus 2017; tersedia secara online (available online) 25 Agustus 2017

\begin{abstract}
Mangrove forest is tropical coastal vegetation that grow on muddy and sandy soils which affected by sea tides. One of important commercial species that live in mangrove ecosystem is the mud crab (Scylla serrata). Feed and water quality have been considered as critical components for supporting the growth both of weight and carapace length of this species. This study was conducted from January to February 2017 in the area of Ecotourism Kampung Kepiting, Bali. The influence of different natural feed such as Jerbung shrimp (Penaeus merguiensis), Mollusca, lemuru fish (Sardinella lemuru) and sea worms (Nereis sp.) on the growth performance of the mud crab were investigated. Water quality parameter data such as $\mathrm{pH}, \mathrm{DO}$, temperature, salinity and ammonium were also collected. The obtained data were analyzed by using variance analysis of Statistical Product and Service Solutions (SPSS) version 21. The result showed that the use of different types of feed have no effect on the length of carapace, but it has significantly influence on the specific growth rate of mud crab. Finally, different types of the given feeding were still resulted in the save range of water quality parameters for mud crab culture.
\end{abstract}

Keywords: mud crab; specific growth rate; length of carapace; water quality

\begin{abstract}
Abstrak
Mangrove merupakan vegetasi pesisir tropis yang tumbuh di tanah berlumpur dan berpasir dan terpengaruh oleh pasang surut air laut. Salah satu spesies komersial penting yang hidup di ekosistem mangrove adalah kepiting bakau (Scylla serrata). Pakan dan kualitas air merupakan komponen penting untuk menunjang pertumbuhan berat dan panjang karapas kepiting bakau. Penelitian ini dilakukan dari bulan Januari sampai Pebruari 2017 di kawasan Ekowisata Kampung Kepiting, Bali. Penelitian ini menginvestigasi tentang pengaruh dari pemberian pakan yang berbeda seperti udang jerbung (Penaeus merguiensis), kekerangan, ikan lemuru (Sardinella lemuru) dan cacing laut (Nereis sp). Adapun data parameter kualitas air yang diambil adalah $\mathrm{pH}, \mathrm{DO}$, suhu, salinitas dan amonium. Data yang diperoleh dianalisis dengan menggunakan analisis variansi menggunakan program Statistical Product and Service Solutions (SPSS) versi 21. Hasil penelitian menunjukkan bahwa pemberian jenis pakan yang berbeda tidak berpengaruh terhadap panjang karapas dan berpengaruh nyata terhadap laju pertumbuhan spesifik kepiting bakau. Selanjutnya semua perlakuan pada penelitian ini masih memberikan rentang kualitas air yang mendukung kehidupan kepiting bakau.
\end{abstract}

Kata Kunci: kepiting bakau; laju pertumbuhan spesifik; panjang karapas; kualitas air 


\section{Pendahuluan}

Hutan mangrove merupakan hutan yang tumbuh pada tanah berlumpur dan berpasir di daerah pantai dan muara sungai yang masih dipengaruhi oleh pasang surut laut. Herianto dan Subiandono (2012) menyatakan bahwa hutan mangrove berperan penting dalam pengembangan perikanan pantai. Hutan mangrove juga merupakan tempat fishing ground dan nursery ground bagi ikan dan kepiting (Kariada dkk. 2014; Sari dan Ekawaty, 2016). Ditinjau dari aspek ekologis, hutan mangrove mempunyai banyak manfaat dan salah satunya adalah sebagai ekowisata. Salah satu daerah ekowisata di Indonesia khususnya di Bali adalah ekowisata Kampung Kepiting yang terletak di Desa Tuban Kabupaten Badung (Felanza dkk., 2017).

Pemeliharaan kepiting bakau perlu didukung dengan pemberian pakan yang sesuai. Komponen dan komposisi pakan menentukan kualitas dari pakan. Komponen tersebut yaitu lemak, protein, vitamin, mineral dan kaerbohidrat, jika kekurangan dari komponen tersebut maka akan menyebabkan terganggunya pertumbuhan kepiting bakau. Kisaran kebutuhan nutrisi untuk pertumbuhan kepiting bakau meliputi kisaran komposisi nutrisi dalam pakan kepiting yakni protein 30-40\% (Serang dkk. 2007).

Tujuan dari penelitian yang ini adalah untuk mengetahui pengaruh perbedaan jenis pakan terhadap pertumbuhan panjang karapas dan berat kepiting bakau (Scylla serrata).

\section{Metode Penelitian}

\subsection{Waktu dan Lokasi Penelitian}

Penelitian dilaksanakan di bak pemeliharaan kepiting bakau di kawasan Ekowisata Kampung Kepiting (Gambar 1). Pengambilan data dilaksanakan pada bulan Januari sampai Pebruari 2017.

\subsection{Alat dan Bahan}

Alat yang dipergunakan dalam penelitian ini terdiri dari bak beton, ember, pipet tetes, benang kasur, penggaris, timbangan digital, nampan, alat tulis, kamera digital, $\mathrm{pH}$ meter, refraktometer, DO meter, thermometer, sekop kecil, talenan, pisau, sikat gigi, kertas label dan aluminium foil. Sedangkan untuk bahan yang digunakan terdiri dari kepiting bakau, cacing laut, kekerangan, ikan lemuru, udang, pasir pantai, formalin dan iodine.

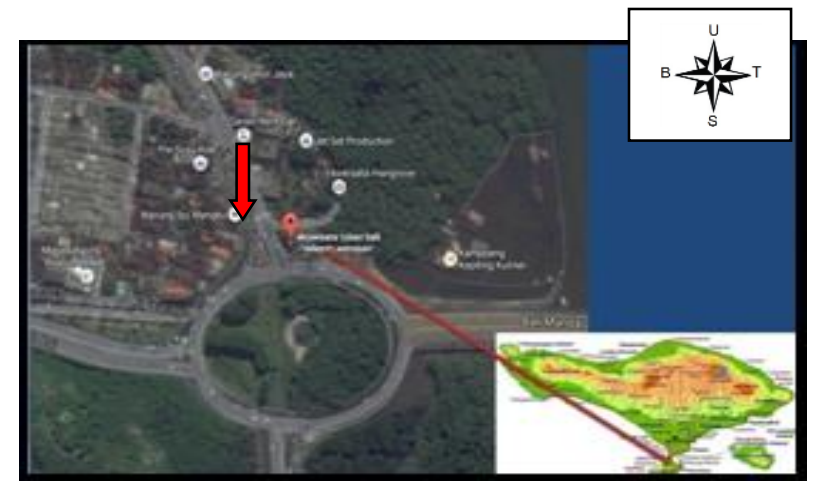

Gambar 1. Peta Lokasi Penelitian

\subsection{Parameter Penelitian}

Parameter utama dalam penelitian ini adalah pertumbuhan spesifik yang meliputi berat tubuh dan panjang karapas kepiting bakau. Parameter pendukung dalam penelitian ini adalah kualitas air yang meliputi suhu, DO (oksigen terlarut), $\mathrm{pH}$ (derajat keasaman), salinitas (kadar garam).

Parameter utama berat kepiting bakau diukur dengan mengukur pertambahan berat. Pengukuran panjang karapas dan berat kepiting bakau dilakukan satu kali seminggu selama penelitian. Menghitung pertambahan berat umumnya menggunakan rumus laju pertumbuhan spesifik yang biasa disebut dengan Spesific Growth Rate (SGR). Laju pertumbuhan spesifik merupakan laju pertumbuhan harian atau presentase pertambahan berat per hari. Laju pertumbuhan spesifik dihitung menggunakan rumus Zuraidha dkk. (2013) sebagai berikut:

$\mathrm{SGR}=\frac{\mathrm{Wt}-\mathrm{Wo}}{t} \times 100 \%$

Keterangan:

SGR : Spesific Growth Rate atau laju pertumbuhan spesifik

Wo : Berat kepiting bakau pada hari ke-0 (g)

Wt : Berat kepiting pada hari ke-t (g)

$\mathrm{T}$ : Lama pemeliharaan

\subsection{Rancangan Percobaan}

Penelitian menggunakan metode Rancangan Acak Lengkap (RAL) dan dilaksanakan di dalam satu bak, sehingga setiap unit dalam percobaan mendapat pengaruh lingkungan yang sama. Kepiting yang dipergunkan yaitu kepiting bakau jantan dengan berat 150-180 g/ekor dan pakan 
yang diberikan 5\% dari berat tubuh. Terdapat empat perlakuan yang diberikan. Setiap perlakuan yang diberikan dilakukan tiga kali ulangan sehingga diperoleh 12 unit percobaan.

\subsection{Analisis Data}

Analisi data menggunakan analisis sidik ragam atau analisis of variance (ANOVA) dengan taraf $5 \%$, artinya rentang kesalahan sebesar $5 \%$ dan data tersebut diyakini benar $95 \%$. Pengujian pada hasil penelitian menggunakan software Statistical Product and Service Solutions (SPSS) versi 21.

\section{Hasil dan Pembahasan}

\subsection{Panjang Karapas Kepiting Bakau}

Hasil pengukuran panjang karapas kepiting bakau yang diberi perlakuan pakan ikan lemuru, cacing, kekerangan dan udang dari minggu ke-1 sampai minggu ke-8 (Gambar 2).

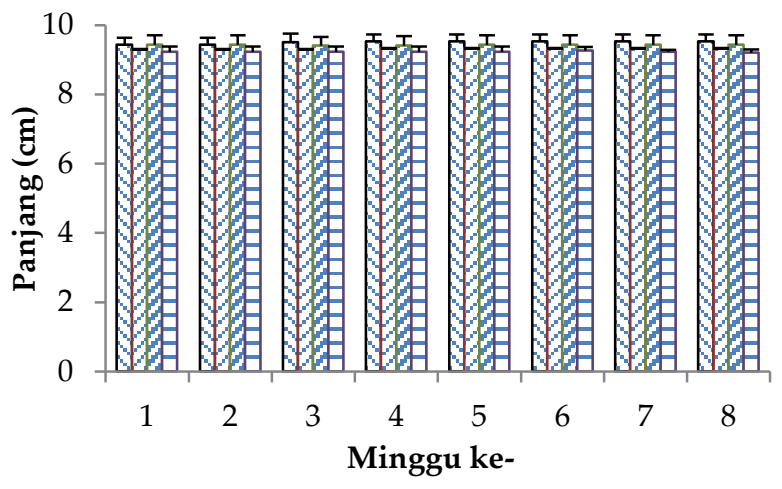

Gambar 2. Panjang Karapas Kepiting Bakau yang diberi Pakan Ikan Lemuru, Kekerangan, Cacing dan Udang

Hasil uji statistik panjang karapas kepiting bakau menunjukkan bahwa kepiting bakau yang diberi perlakuan pakan ikan lemuru, kekerangan, cacing dan udang tidak berbeda secara signifikan. Hal ini dilihat dari hasil uji statistik sidik ragam (ANOVA) yaitu $p>0,05$ yang menunjukkan bahwa perbedaan jenis pakan tidak memberikan pengaruh yang signifikan terhadap panjang karapas kepiting bakau selama pemeliharaan.

Rata-rata panjang karapas kepiting bakau dari minggu ke-1 sampai minggu ke-8 tidak mengalami peningkatan yang signifikan. Hal ini dikarenakan kepiting tidak mengalami molting dan kepiting yang dipergunakan adalah kepiting dewasa dengan berat 150-180 gr/ekor. Muswantoro dkk.
(2012) menyatakan bahwa pada fase dewasa dengan berat diatas 70 gr/ekor, kepiting hanya mengalami pertambahan bobot dan untuk pertumbuhan hanya terjadi pada saat kepiting mengalami molting. Hasil di lapangan menunjukkan terdapat lumut yang menempel pada karapas kepiting bakau. Hal ini diduga menjadi penyebab kepiting bakau stres dan terhambatnya molting. Sagala dkk. (2013) menyatakan bahwa lumut yang terdapat pada bagian tubuh dari kepiting bakau dapat menghambat proses terjadinya molting bahkan dapat menyebabkan kematian.

\subsection{Berat Kepiting Bakau}

3.2.1 Berat Kepiting Bakau dengan Pakan Ikan Lemuru

Berdasarkan Gambar 3 diketahui bahwa berat kepiting bakau yang diberi pakan ikan lemuru mengalami fluktuasi berat selama delapan minggu pemeliharaan. Berat kepiting bakau yang diberi perlakuan pakan ikan lemuru pada minggu ke-2 mengalami kenaikan sebesar 2,27 gr dibandingkan berat minggu ke-1. Selanjutnya berat kepiting bakau tidak mengalami perubahan yang signifikan dari minggu ke-2 sampai minggu ke-3. Terjadi penurunan berat kepiting bakau sebesar 9,7 gr pada minggu ke-4 dan sebesar 4,3 gr pada minggu ke-5 dibandingkan berat pada satu minggu sebelumnya. Berat kepiting bakau mulai meningkat kembali pada minggu ke-6 yaitu sebesar 10,7 gr dan pada minggu ke-8 sebesar 0,4 gr dibandingkan berat pada satu minggu sebelumnya.

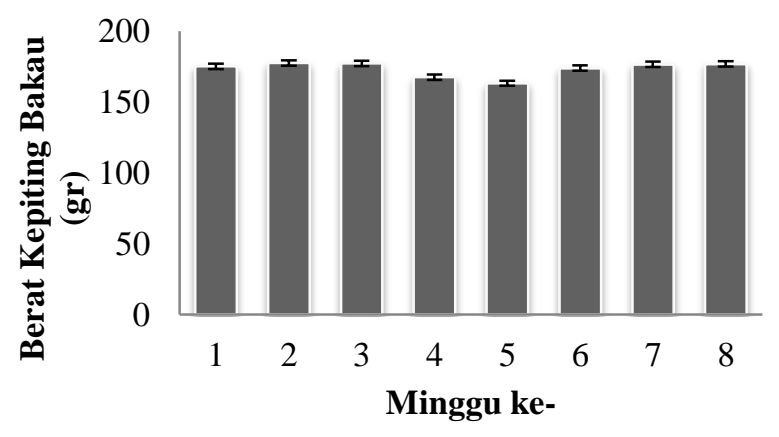

Gambar 3. Berat Kepiting Bakau yang diberi Pakan Ikan Lemuru

Berat kepiting bakau yang diberi perlakuan pakan ikan lemuru dari minggu ke-1 sampai 
minggu ke-3 mengalami peningkatan. Hal ini dikarenakan kepiting bakau sudah mulai beradaptasi dengan lingkungannya dan kualitas lingkungan juga mendukung untuk pertumbuhan dari kepiting bakau. Pertambahan berat kepiting bakau secara keseluruhan dipengaruhi oleh pakan dan kualitas lingkungan yang mendukung Fadnan dkk. (2010). Jika dilihat dari kandungan gizi yang terdapat pada ikan lemuru dalam pernyataan BKPP (2014) yang menyatakan bahwa ikan lemuru mempunyai kandungan protein $20 \%$, karbohidrat $0 \%$ dan lemak $3 \%$ sudah cukup untuk menunjang pertumbuhan dari kepiting bakau.

Terjadi penurunan berat kepiting bakau pada minggu ke-4 dan minggu ke-5. Hal ini diduga disebabkan oleh kualitas pakan yang kurang segar karena pakan yang diberikan pada minggu ke-4 dan ke-5 berupa pakan beku. Kualitas pakan yang kurang segar menyebabkan efisiensi pemanfaatan pakan rendah sehingga terjadi penurunan berat pada kepiting bakau. Pernyataan ini didukung oleh Sari dkk. (2009) yang menyatakan bahwa efisiensi pemanfaatan pakan oleh organsime budidaya menunjukkan seberapa besar nilai pakan yang termanfaatkan oleh tubuh dikarenakan pertumbuhan dipengaruhi oleh kualitas pakan yang diberikan.

Berat kepiting bakau dari minggu ke-6 sampai minggu ke-8 mulai mengalami kenaikan dikarenakan ketersediaan pakan segar tercukupi dan kepiting bakau mulai diberikan pakan segar kembali. Pakan segar dipilih karena memiliki kandungan nutrisi yang lebih baik jika di bandingkan dengan pakan beku (kurang segar). Selain itu karakteristik dari pakan segar yang cenderung tenggelam menyebabkan kepiting bakau mudah untuk memakan makanannya dikarenakan tekstur dari pakan tersebut masih dalam kondisi bagus. Hal ini sesuai dengan pernyataan dari Septian dkk. (2013) yang menyatakan bahwa pakan segar bersifat tenggelam sehingga peluang pakan tersebut dimakan oleh kepiting lebih besar dikarenakan kepiting mempunyai sifat lebih suka mencari pakan di dasar.

3.2.2 Berat Kepiting Bakau dengan Pakan Kekerangan

Berdasarkan hasil yang didapat, berat kepiting bakau yang diberi perlakuan pakan kekerangan mengalami fluktuasi berat selama delapan minggu pemeliharaan (Gambar 4). Berat kepiting bakau yang diberi perlakuan pakan kekerangan mengalami kenaikan sebesar 6,33 gr pada minggu ke-2 dibandingkan berat pada minggu ke-1. Selanjutnya berat kepiting bakau tidak mengalami perubahan yang signifikan dari minggu ke-2 sampai minggu ke-3. Terjadi penurunan berat kepiting bakau sebesar 6 gr pada minggu ke-4 dan sebesar 7 gr pada minggu ke-5 dibandingkan berat pada satu minggu sebelumnya. Berat kepiting bakau mulai meningkat kembali pada minggu ke-6 yaitu sebesar 5,3 gr dan pada minggu ke-8 sebesar 7,7 gr dibandingkan berat pada satu minggu sebelumnya.

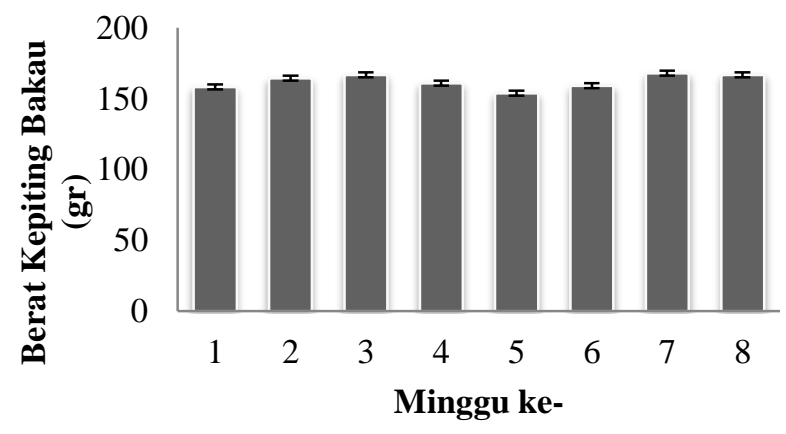

Gambar 4. Berat Kepiting Bakau yang diberi Pakan Kekerangan

Pertambahan berat kepiting bakau yang diberi perlakuan pakan kekerangan dari minggu ke-1 sampai minggu ke-3 mengalami kenaikan. Hal ini diduga perlakuan pakan kekerangan mempunyai tekstur pakan yang padat sehingga memudahkan kepiting bakau untuk mencapit dan memakan makanannya. Hal ini sesuai dengan pola makan kepiting bakau dalam mendapatkan makanan dengan cara mencapit. Pernyataan ini sesuai dengan Rangka (2007) yang menyatakan bahwa, pola makan kepiting bakau adalah dengan cara memegang pakan menggukan capit sebelum pakan tersebut dimasukkan kedalam mulut untuk dimakan.

Penurunan berat kepiting bakau yang terjadi pada minggu ke-4 sampai minggu ke-5. Hal ini diduga disebabkan oleh kualitas pakan yang diberikan kurang segar. Kualitas pakan yang kurang segar menyebabkan efisiensi pemanfaatan pakan rendah sehingga terjadi penurunan berat pada kepiting bakau. Pernyataan ini didukung oleh Sari dkk. (2009) yang menyatakan bahwa efisiensi pemanfaatan pakan oleh organsime budidaya menunjukkan seberapa besar nilai pakan 
yang termanfaatkan oleh tubuh organisme dikarenakan pertumbuhan dipengaruhi oleh kualitas pakan yang dikonsumsi

Berat kepiting bakau mulai meningkat kembali pada minggu ke-6 sampai minggu ke-8. Hal ini diduga pemberian pakan segar yang diberikan mengandung nutrisi yang diperlukan untuk menunjang pertumbuhan dari kepiting bakau. Sari dkk. (2009) menyatakan bahwa pakan dengan kualitas baik berpengaruh terhadap pertumbuhan. Jika dilihat dari kandungan nutrisi, BKPP (2014) menyatakan bahwa jenis kekerangan memiliki kandungan protein sebesar 8 gr, kandungan karbohidrat sebesar 3,6 gr, kandungan lemak sebesar 1,1 gr dan air 85 gr (BKPP 2014).

\subsubsection{Berat Kepiting Bakau dengan Pakan Cacing}

Berdasarkan hasil yang didapat menunjukkan bahwa, berat kepiting bakau yang diberi perlakuan pakan cacing mengalami fluktuasi berat selama pemeliharaan (Gambar 5). Berat kepiting bakau yang diberi perlakuan pakan cacing mengalami kenaikan sebesar 3 gr pada minggu ke2 dibandingkan berat minggu ke-1. Selanjutnya berat kepiting bakau tidak mengalami kenaikan berat yang signifikan dari minggu ke-2 sampai minggu ke-3. Terjadi penurunan berat kepiting bakau sebesar 2 gr pada minggu ke-4 dan sebesar 14 gr pada minggu ke-5 dibandingkan berat pada satu minggu sebelumnya. Berat kepiting bakau mulai meningkat kembali pada minggu ke-6 sebesar 17 gr dan penurunan pada minggu ke-8 sebesar 1 gr dibandingkan berat pada satu minggu sebelumnya.

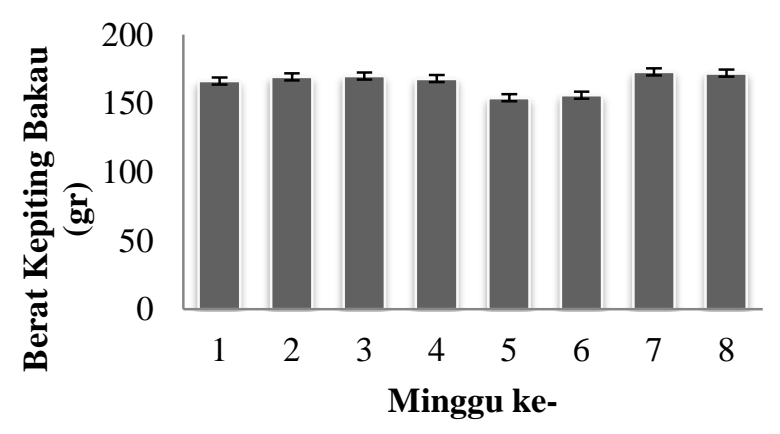

Gambar 5. Berat Kepiting Bakau yang diberi Pakan Cacing

Pertambahan berat kepiting bakau yang diberi perlakuan pakan cacing dari minggu ke-1 sampai minggu ke-3 mengalami kenaikan berat dikarenakan kepiting bakau mulai beradaptasi dengan lingkungan yang baru. Terjadi penurunan berat kepiting bakau pada minggu ke-4 dan minggu ke-5. Hal ini diduga disebabkan oleh kualitas pakan yang kurang segar. Kualitas pakan yang kurang segar menyebabkan efisiensi pemanfaatan pakan rendah yang mengakibatkan penurunan berat. Pernyataan ini didukung oleh Sari dkk. (2009) yang menyatakan bahwa efisiensi pemanfaatan pakan oleh organsime budidaya menunjukkan seberapa besar nilai pakan yang termanfaatkan oleh tubuh dikarenakan pertumbuhan dipengaruhi oleh kualitas pakan.

Berat kepiting bakau perlakuan pakan cacing mulai meningkat pada minggu ke-6 sampai minggu ke-8. Hal ini dikarenakan pakan yang diberikan merupakan pakan segar, sehingga pakan yang dikonsumsi termanfaatkan dengan maksimal.

\subsubsection{Berat Kepiting Bakau dengan Pakan Udang}

Berdasarkan hasil yang didapat menunjukkan bahwa, berat kepiting bakau yang diberi pakan udang mengalami fluktuasi berat selama delapan minggu pemeliharaan (Gambar 6). Berat kepiting bakau yang diberi perlakuan pakan udang pada minggu ke-2 mengalami kenaikan sebesar 11 gr dibandingkan berat minggu ke-1. Selanjutnya berat kepiting bakau tidak mengalami perubahan yang signifikan dari minggu ke-2 sampai minggu ke-3. Terjadi penurunan berat kepiting bakau sebesar 6 gr pada minggu ke-4. Berat kepiting bakau mulai meningkat kembali pada minggu ke-5 yaitu sebesar 2 gr dan pada minggu ke-8 sebesar $0,7 \mathrm{gr}$.

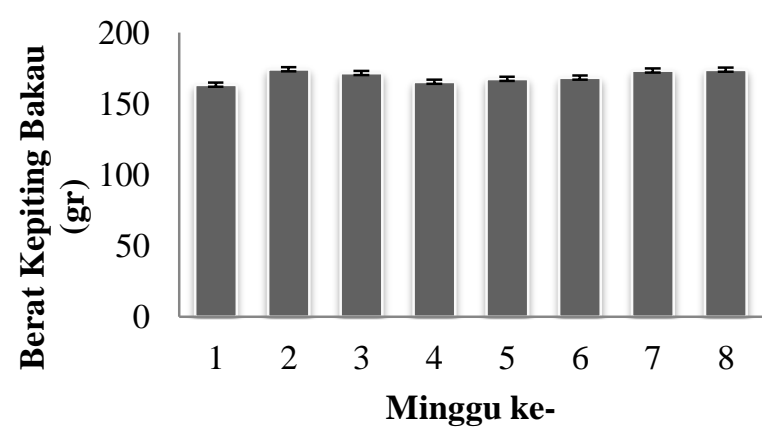

Gambar 6. Berat Kepiting Bakau yang diberi Pakan Udang

Pertambahan berat kepiting bakau yang diberi perlakuan pakan udang dari minggu ke-1 sampai minggu ke-2 mengalami kenaikan berat. Hal ini 
dikarenakan pakan yang diberikan merupakan pakan segar. Kandungan gizi yang terdapat pada perlakuan pakan udang juga mencukupi untuk pertumbuhan dari kepiting bakau. Kandungan nutrisi yang terdapat pada udang per 100 gr yaitu air 20,31 gr dan karbohidrat 0,91 gr. Pemberian pakan yang tepat dalam penelitian ini yaitu pemberian pakan segar yang mempertimbangkan kualitas, merupakan faktor penentu keberhasilan pertumbuhan kepiting bakau.

Penurunan berat kepiting bakau terjadi pada minggu ke-3 dan minggu ke-4. Hal ini dikarenakan terdapat sisa pakan pada media pemeliharaan kepiting bakau. Sisa pakan yang tertinggal akan mengalami pembusukan sehingga berpengaruh terhadap kualitas media pemeliharaan yang menyebabkan nafsu makan kepiting terganggu (Sulardiono dkk. 2013). Berat kepiting bakau minggu ke-5 sampai minggu ke-8 mulai meningkat dibandingkan minggu sebelumnya. Terlihat dari berkurangnya sisa pakan yang ada di dasar media pemeliharaan sehingga energi yang diperoleh dari pakan termanfaatkan secara maksimal. Yeager and Layman, (2011) menyatakan bahwa energi yang terkandung dalam pakan dibutuhkan oleh kepiting bakau untuk mengganti sel yang rusak, adaptasi, metabolisme, aktivitas, reproduksi dan pertumbuhan.

\subsection{Laju Pertumbuhan Spesifik}

Hasil uji statistik laju pertumbuhan spesifik kepiting bakau menunjukkan bahwa berat kepiting bakau yang diberi pakan udang berbeda secara signifikan dengan berat kepiting bakau yang diberi pakan ikan lemuru, kekerangan dan cacing (Gambar 7). Hal ini dilihat dari hasil uji statistik sidik ragam (ANOVA) yaitu $\mathrm{p}<0,05$ yang menunjukkan bahwa perbedaan jenis pakan yang diberikan signifikan terhadap laju pertumbuhan spesifik kepiting bakau. Selanjutnya dilakukan uji lanjutan yaitu uji Duncan yang menunjukkan bahwa perlakuan pakan udang memberikan hasil yang berbeda signifikan dan memiliki nilai laju pertumbuhan spesifik tertinggi yaitu sebesar 1,24\% jika dibandingkan dengan perlakuan pakan ikan lemuru yang hanya sebesar $0,43 \%$. Namun laju pertumbuhan spesifik yang dihasilkan pada perlakuan pakan kekerangan yaitu sebesar 0,99\% dan pada perlakuan pakan cacing sebesar $0,68 \%$ menunjukkan perbedaan yang tidak signifikan sehingga laju pertumbuhan spesifik paling baik pada penelitian ini adalah pada perlakuan pakan udang.

Hasil uji statistik laju pertumbuhan spesifik kepiting bakau menunjukkan bahwa perlakuan pakan udang memberikan laju pertumbuhan yang signifikan terhadap laju pertumbuhan spesifik kepiting bakau yang diberi perlakuan pakan ikan lemuru, cacing dan kekerangan. Hal ini diduga karena udang mempunyai tekstur yang padat dan tidak mudah hancur sehingga memudahkan kepiting bakau mencapit dan memakan makanannya. Pernyataan ini sesuai dengan Rangka (2007) yang menyatakan bahwa kepiting bakau mempunyai pola kebiasaan makan dengan cara mencapit kemudian memasukan makanannya ke dalam mulut.

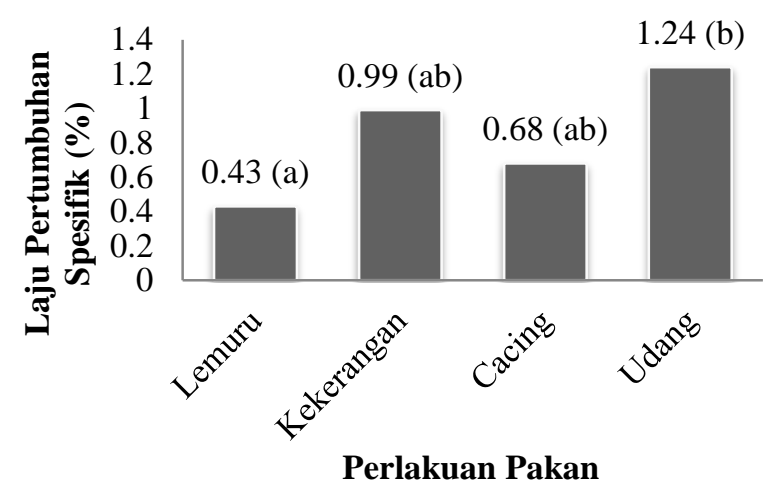

Ket: Huruf yang sama menunjukkan perbedaan yang tidak signifikan ( $p>0,05$ )

Gambar 7. Laju Pertumbuhan Spesfik Kepiting Bakau

Kepiting bakau memerlukan energi untuk pertumbuhan. Kebutuhan tersebut meliputi protein, karbohidrat, lemak, vitamin, mineral dan air. Menurut BKPP (2014) ikan lemuru mempunyai kandungan protein $20 \%$, karbohidrat $0 \%$ dan lemak 3\%. Jenis kekerangan memiliki kandungan protein sebesar $8 \mathrm{gr}$, kandungan karbohidrat sebesar 3,6 gr, kandungan lemak sebesar 1,1 gr dan air 85 gr (BKPP 2014). Munairi dkk. (2012) menyatakan bahwa cacing laut (Nereis sp.) atau sering disebut dengan cacing lur mempunyai kandungan karbohidrat sebesar $15,3 \%$, protein sebesar 3,08\%, lemak sebesar $0 \%$ dan air sebesar $78,4 \%$ dimana kandungan nutrisi ini dibutuhkan untuk pertumbuhan. Walaupun ketiga pakan tersebut mempunyai kandungan nutrisi yang cukup, namun dari hasil penelitian menunjukkan bahwa pakan udang merupakan pakan yang disukai dari kepiting bakau. Kandungan nutrisi udang per 100 gr diantaranya adalah air sebesar 
$75,86 \mathrm{gr}$, lemak total sebesar 1,73 gr, protein sebesar 20,31 gr dan karbohidrat sebesar 0,91 gr.

Perbandingan hasil di lapangan, kepiting bakau yang diberi pakan ikan lemuru, kekerangan dan cacing menunjukkan bahwa jika pakan terlalu lama terendam air, mulai tidak segar dan mendekati busuk pakan tersebut akan mengapung di permukaan. Pakan yang terapung di permukaan menyebabkan kepiting bakau sulit untuk memakan makananya. Sifat pakan segar tenggelam, sehingga besar peluang pakan tersebut dimakan, dikarenakan kepiting bakau mempunyai sifat lebih suka mencari pakan di dasar (Septian dkk. 2013).

\subsection{Kualitas Air Selama Pemeliharaan}

Berdasarkan data pada Tabel 1 dapat dilihat bahwa hasil rata-rata pengukuran $\mathrm{pH}$ di bak pemeliharaan kepiting bakau yang diberi perlakuan pakan ikan lemuru, kekerangan, cacing dan udang adalah 7,4-7,9. Dilanjutkan dengan hasil rata-rata pengukuran DO pada bak pemeliharaan kepiting bakau adalah 3,9-8,4 ppm. Hasil rata-rata pengukuran suhu berkisar antara $27-28,8^{\circ} \mathrm{C}$. Hasil rata-rata pengukuran salinitas pada bak pemeliharaan kepiting bakau berkisar 16-27 ppt. Hasil pengukuran amonium pada bak pemeliharaan kepiting bakau diketahui bahwa kadar amonium rata-rata pada bak pemeliharaan kepiting adalah 0,6-0,8 mg/l.

Tabel 1.

Pengukuran Kualitas Air

\begin{tabular}{llll}
\hline No & Parameter & Satuan & Kisaran hasil \\
\hline 1 & pH & - & $7,4-7,9$ \\
2 & DO & ppm & $3,9-8,4$ \\
3 & Suhu & ${ }^{\circ} \mathrm{C}$ & $27-28,8$ \\
4 & Salinitas & $\mathrm{ppt}$ & $16-27$ \\
5 & Amonium & $\mathrm{mg} / \mathrm{l}$ & $0,6-0,8$ \\
\hline
\end{tabular}

Pengukuran $\mathrm{pH}$ pada media pemeliharaan kepiting bakau yang diberi perlakuan pakan ikan lemuru, kekerangan, cacing dan udang pada minggu ke-1 sampai minggu ke-8 masih sesuai yaitu berkisar antara 7,4-7,9. Kadar pH untuk pemeliharaan cenderung stabil karena dilakukan sirkulasi setiap hari pada bak pemeliharaan kepiting. Pengukuran kualitas air selalu dilakukan rutin setiap seminggu sekali untuk mengontrol kondisi perairan pada bak pemeliharaan. Purba (2012) menyatakan bahwa $\mathrm{pH}$ yang dianjurkan untuk pertumbuhan kepiting bakau yaitu berkisar 7,7-8,7. Kondisi ini masih dalam keadaan sesuai untuk pertumbuhan dan pemeliharaan kepiting bakau.

Pengukuran amonium pada media pemeliharaan kepiting bakau yang diberi perlakuan pakan ikan lemuru, kekerangan, cacing dan udang pada minggu ke-1 sampai minggu ke-8 masih sesuai yaitu berkisar antara 0,6-0,8 mg/l. Kebersihan bak pemeliharaan kepiting selalu di kontrol dan sisa pakan yang mengendap di dasar bak rutin dibersihkan setiap hari sebelum dilakukan sirkulasi. Pengurasan bak pemeliharaan dilakukan setiap satu minggu sekali untuk membersihkan sisa pakan yang tidak dapat di jangkau pada dasar bak. Amonium pada bak pemeliharaan masih stabil untuk pemeliharaan dan pertumbuhan kepiting bakau. Nilai kelayakan amonium adalah < $1 \mathrm{mg} / \mathrm{l}$ (Quinitio and ParadoEstepa, 2003; Liao et al., 2011; Romano and Zeng, 2011).

Pengukuran DO atau oksigen terlarut pada media pemeliharaan kepiting bakau yang diberi perlakuan pakan ikan lemuru, kekerangan, cacing dan udang pada minggu ke-1 sampai minggu ke-8 masih sesuai yaitu berkisar antara 3,9-8,4 ppm. Kisaran tersebut masih dalam batas toleransi untuk pertumbuhan kepiting bakau sehingga sesuai untuk menunjang pertumbuhan kepiting bakau. Hal ini sesuai dengan pendapat Saputra dkk. (2012) yang menyatakan bahwa, jika kandungan oksigen terlarut dalam perairan $>4$ ppm masih dalam kategori baik untuk kehidupan kepiting bakau. Konsumsi oksigen merupakan salah satu parameter fisiologis yang dapat digunakan untuk menaksir laju metabolisme secara tidak langsung, yaitu dengan mengukur oksigen yang digunakan dalam proses oksidasi. Kisaran oksigen terlarut yang sesuai untuk kehidupan kepiting bakau berkisar antara 3-15 ppm.

Pengukuran suhu pada bak pemeliharaan kepiting bakau yang diberi perlakuan pakan ikan lemuru, kekerangan, cacing dan udang pada minggu ke-1 sampai minggu ke-8 masih sesuai yaitu berkisar antara $27-28,8^{\circ} \mathrm{C}$. Pengukuran suhu dilakukan seminggu sekali pada pukul 10.00 WITA sebelum dilakukan sirkulasi air pada media 
pemeliharaan kepiting bakau. Kondisi ini masih dalam kisaran normal dan layak untuk pertumbuhan kepiting bakau. Idha dkk. (2013) menyatakan bahwa keiting baau dapat hidup dan tumbuh dengan baik pada kisaran suhu $23-32^{\circ} \mathrm{C}$.

Pengukuran salinitas pada media pemeliharaan kepiting bakau yang diberi perlakuan pakan ikan lemuru, kekerangan, cacing dan udang pada minggu ke-1 sampai minggu ke-8 masih sesuai yaitu berkisar antara 16-27 ppt. Hal ini sesuai dengan pernyataan Saputra dkk. (2011) yang menyatakan bahwa kisaran salinitas yang optimal untuk pertumbuhan kepiting bakau adalah 28-30 ppt.

\section{Simpulan}

Perbedaan jenis pakan yang diberikan tidak berpengaruh terhadap panjang karapas kepiting bakau. Perbedaan jenis pakan yang diberikan berpengaruh terhadap berat kepiting bakau, dan pakan udang merupakan pakan yang paling efektif untuk pertumbuhan kepiting bakau dibandingkan dengan ketiga perlakuan lainnya. Pengukuran kualitas air dalam bak pemeliharaan menunjukkan bahwa masih dalam batas toleransi untuk kehidupan pemeliharaan kepiting bakau.

\section{Ucapan terima kasih}

Terima kasih yang sebesar-besarnya penulis ucapkan Ekowisata Kampung Kepiting, temanteman Manajemen Sumberdaya Perairan dan Ilmu Kelautan serta semua pihak yang membantu demi kelancaran penelitian.

\section{Daftar Pustaka}

BKPP, 2014. http://diperpautkan.bantulkab.go.id/ (6 Juni 2017)

Fadnan, M., Iromo, H., \& Azis. (2010). Pengaruh padat tebar yang berbeda terhadap pertumbuhan dan kelangsungan hidup pada penggemukan kepiting bakau (Scylla sp.). Jurnal Harpodon Borneo, 3(2), 61-69.

Felanza, M., Nugroho, W. B., \& Kebayantini, N. L. N. (2017). Pemberdayaan Kelompok Nelayan Wanasari Tuban Melalui Implementasi CSR PT. Pertamina (PERSERO) DPPU Ngurah Rai. Jurnal Ilmiah Sosiologi (SOROT), 1(1), 1-13.

Heriyanto, N. M., \& Subiandono, E., (2012). Komposisi dan Struktur Tegakan, Biomasa, dan
Potensi Kandungan Karbon Hutan Mangrove di Taman Nasional Alas Purwo. Jurnal Penelitian Hutan dan Konservasi Alam, 9(1), 23-32.

Asyhariyati, A., I., Samidjan, I., \& Rachmawati, D. (2013). Pemberian Kombinasi Pakan Koeng Macan Dan Ikan Rucah Terhadap Pertumbuhan Dan Kelulushidupan Kepiting Bakau (Scylla paramamosain). Journal of Aquaculture Management and Technology, 2(4), 131-138.

Kariada, T. M., \& Andin, I., (2014). Peranan Mangrove sebagai Biofilter Pencemaran Air Wilayah Tambak Bandeng, Semarang. Jurnal Manusia dan Lingkungan, 21(2):188-194.

Liao, Y. Y., Wang, H. H., \& Lin, Z. G. (2011). Effect of ammonia and nitrite on vigour, survival rate, moulting rate of the blue swimming crab Portunus pelagicus zoea. Aquaculture international, 19(2), 339-350.

Munairi, A., \& Abida, I. W. (2012). Studi Kepadatan dan Pola Distribusi Cacing Lur (Nereis sp) di Perairan Pesisir Kecamatan Kwanyar Kabupaten Bangkalan. Jurnal Kelautan: Indonesian Journal of Marine Science and Technology, 5(1), 47-51

Muswantoro, A. P., Supriyantini, E., \& Djunaidi, A. (2012). Penambahan Berat, Panjang dan Lebar dari Ukuran Benih yang Berbeda pada Budidaya Kepiting Soka di Desa Mojo Kabupaten Pemalang. Journal of Marine Research, 1(1), 95-99.

Purba, C. Y. (2012). Performa Pertumbuhan, Kelulushidupan, dan Kandungan Nutrisi Larva Udang Vanamei (Litopenaeus Vannamei) Melalui Pemberian Pakan Artemia Produk Lokal yang Diperkaya dengan Sel Diatom. Journal of Aquaculture Management and Technology. 1(1),102-115.

Quinitio, E. T., \& Parado-Estepa, F. D. (2003). Biology and hatchery of mud crabs Scylla spp. Tigbauan, Iloilo, Philippines: Aquaculture Department, Southeast Asian Fisheries Development Center.

Rangka, N. A. (2007). Status usaha kepiting bakau ditinjau dari aspek peluang dan prospeknya. Jurnal Neptunus, 14(1), 90-100.

Romano, N., \& Zeng, C. (2011). Importance of balanced $\mathrm{Na}+/ \mathrm{K}+$ ratios for blue swimmer crabs, Portunus pelagicus, to cope with elevated ammonia- $\mathrm{N}$ and differences between in vitro and in vivo gill $\mathrm{Na}+/ \mathrm{K}+-\mathrm{ATPase}$ responses. Aquaculture, 318(1), 154-161. 
Sagala, L. S. S., Idris, M., \& Ibrahim, M. N. (2013). Perbandingan Pertumbuhan Kepiting Bakau (Scylla serrata) Jantan dan Betina Pada Metode Kurungan Dasar. Jurnal Mina Laut Indonesia, 3(12), 46-54.

Sari, A. H. W., \& Ekawaty, R. (2016). Profil Hemosit dan Aktifitas Fagositosis Kepiting Bakau (Scylla sp.) yang Terserang Ektoparasit di Ekosistem Mangrove Kuta Selatan, Bali. Journal of Marine and Aquatic Sciences, 2(1), 34-39.

Sari, W. P., Agustono, A., \& Cahyoko, Y. (2009). Pemberian Pakan Dengan Energi yang Berbeda Terhadap Pertumbuhan Benih Ikan Kerapu Tikus (Cromileptes altivelis). Ilmiah Perikanan dan Kelautan, 1(2), 149-156.

Saputra, S., Ibrahim, M. N., \& Yusnaini, Y. (2011). Sintasan dan Pertumbuhan Larva Kepiting Bakau (Scylla paramamosain) Zoea 2 Sampai Zoea 5 Melalui Pemberian Jenis Bakteri Probiotik yang Berbeda. Jurnal Mina Laut Indonesia, 3(12), 81-93.

Septian, R., Samijan, I., \& Rachmawati, D. (2013). Pengaruh Pemberian Kombinasi Pakan Ikan Rucah Dan Buatan Yang Diperkaya Vitamin E
Terhadap Pertumbuhan Dan Kelulushidupan Kepiting Soka (Scylla paramamosain). Journal of Aquaculture Management and Technology, 2(1), 1324.

Serang, A. M., Suprayudi, M. A., Jusadi, D., \& Mokoginta, I. (2007). Pengaruh Kadar Protein dan Rasio Energi Protein Pakan Berbeda terhadap Kinerja Pertumbuhan Benih Rajungan (Portunus pelagicus). Jurnal Akuakultur Indonesia, 6(1), 55-63.

Sulardiono, B., Supriharyono, S., \& Susanti, R. (2013). Kajian tentang Laju Pertumbuhan Ikan Bandeng (Chanos chanos Forskall) pada Tambak Sistem Silvofishery dan Non Silvofishery di Desa Pesantren Kecamatan Ulujami Kabupaten Pemalang. Journal of Management of Aquatic Resources, 2(2), 81-86.

Yanti, Z., Muchlisin, Z. A. \& Sugito, S. (2013). Pertumbuhan dan kelangsungan hidup benih ikan nila (Oreochromis niloticus) pada beberapa konsentrasi tepung daun jaloh (Salix tetrasperma) dalam pakan. DEPIK Jurnal IlmuIlmu Perairan, Pesisir dan Perikanan, 2(1), 16-19.

(C) 2017 by the authors; licensee Udayana University, Indonesia. This article is an open access article distributed under the terms and conditions of the Creative Commons Attribution license (http://creativecommons.org/licenses/by/3.0/). 